\title{
ENSAIOS DE IMPACTO DO TIPO IZOD EM COMPÓSITOS EPOXÍDICOS REFORÇADOS COM FIBRAS DE PALF*
}

\author{
Gabriel Oliveira Glória ${ }^{1}$ \\ Maria Carolina Andrade Teles ${ }^{1}$ \\ Giulio Altoé Rodrigues ${ }^{2}$ \\ Maycon de Almeida Gomes ${ }^{3}$ \\ Frederico Muylaert Margem 4 \\ Carlos Maurício Fontes Vieira ${ }^{5}$ \\ Sérgio Neves Monteiro ${ }^{6}$
}

\begin{abstract}
Resumo
Em busca de materiais ecologicamente corretos, a sociedade pode optar pelas fibras naturais na substituição das sintéticas. Uma boa opção entre as fibras naturais está a fibra de PALF, mas não há informações sobre a resistência ao impacto de compósitos de epóxi incorporadas com fibras de PALF. Portanto, o objetivo deste estudo foi investigar as propriedades mecânicas em testes izod, de compósitos epoxídicos incorporados com até 30\% em volume de fibras de PALF. Os resultados demonstraram que a fibra PALF aumenta a resistência ao impacto dos compósitos poliméricos.
\end{abstract}

Palavras-Chave: Fibra de PALF; Fibras naturais; Ensaio de impacto.

\section{IZOD IMPACT TESTS OF EPOXY COMPOSITES REINFORCED WITH PALF FIBERS}

\begin{abstract}
In the searching for environmentally friendly materials, the society may choose the natural fibers to substitute the synthetic ones. As a good option among the natural fibers is the PALF fiber, but there is limited information about the impact resistance of epoxy composites incorporated with PALF fibers. Therefore, the objective of this study was investigate the mechanical properties in izod tests of epoxy composites incorporated with up to $30 \%$ in volume of PALF fibers. The results demonstrated that the PALF fiber increase the impact resistance of polymer composites.
\end{abstract}

Keywords: PALF fibers; Natural fibers; Izod impact test.

1 Graduando(a) em Engenharia Metalúrgica e de Materiais, bolsista de iniciação científica, LAMAV, UENF, Campos dos Goytacazes, Rio de Janeiro - Brasil.

2 Engenheiro Metalúrgico e de Materiais, Mestrando em Engenharia Mecânica, PUC-RJ, Rio de Janeiro - Brasil

3 Engenheiro de Produção, Doutor em Ciência e Engenharia de Materiais, IFF-Centro, Campos dos Goytacazes, Rio de Janeiro - Brasil.

4 Engenheiro de Produção, Doutor em Ciência e Engenharia de Materiais, Pós-Doutorando, LAMAV, UENF, Campos dos Goytacazes, Rio de Janeiro - Brasil.

5 Engenheiro Mecânico, Doutor em Engenharia e ciência dos materiais pela UENF, Campos dos Goytacazes, Rio de Janeiro - Brasil.

6 Engenheiro Metalúrgico, Doutor, Professor, IME, Rio de Janeiro, Rio de Janeiro - Brasil. 


\section{INTRODUCTION}

The natural fibers extracted from cellulose-containing are been investigated to replace the synthetic ones in polymer composites for the purpose of searching environmentally friendly materials. The natural fibers are considered an environmentally correct alternative to replace, non recyclable, energy-intensive and including more expensive synthetic fibers, like the glass fiber, because they are extracted are abundant, biodegradable, renewable, recyclable and above all, neutral with respect to carbon dioxide emission, associated with global warming and greenhouse effect [1-3].

The objective of this works was to analyze the absorbed izod impact energy of the epoxy composites reinforced with continuous and aligned PALF fibers, because previous works indicated that the incorporation of lignocellulosic fibers in polymeric matrix gives rise to composites with mechanical resistance directly proportional of the fiber content $[4,5]$, where these fibers act as reinforcement for matrix due to their high mechanical properties.

\section{MATERIALS AND METHODS}

The basic material used in this work was the PALF fiber supplied by Desigan Natural Fibers and a diglycidyl ether of the bisphenol A (DGEBA) epoxy resin and TETA hardener (trietylene tetramine) was used as matrix.

One hundred PALF fibers, shown in fig. 1, were randomly selected from the packet, the equivalent diameter corresponding to the average between the larger and smaller $\left(90^{\circ}\right.$ rotation) cross section dimensions at five locations for each fiber, was measured in a profile projector Nikon 6C.

Figure 2 presents histogram corresponding to the distribution of diameter of the as-received PALF fibers. The equivalent diameter of each fiber was actually the average value obtained by 10 different measurements performed in a profile projector at five distinct locations (two with $90^{\circ}$ rotation at each location).

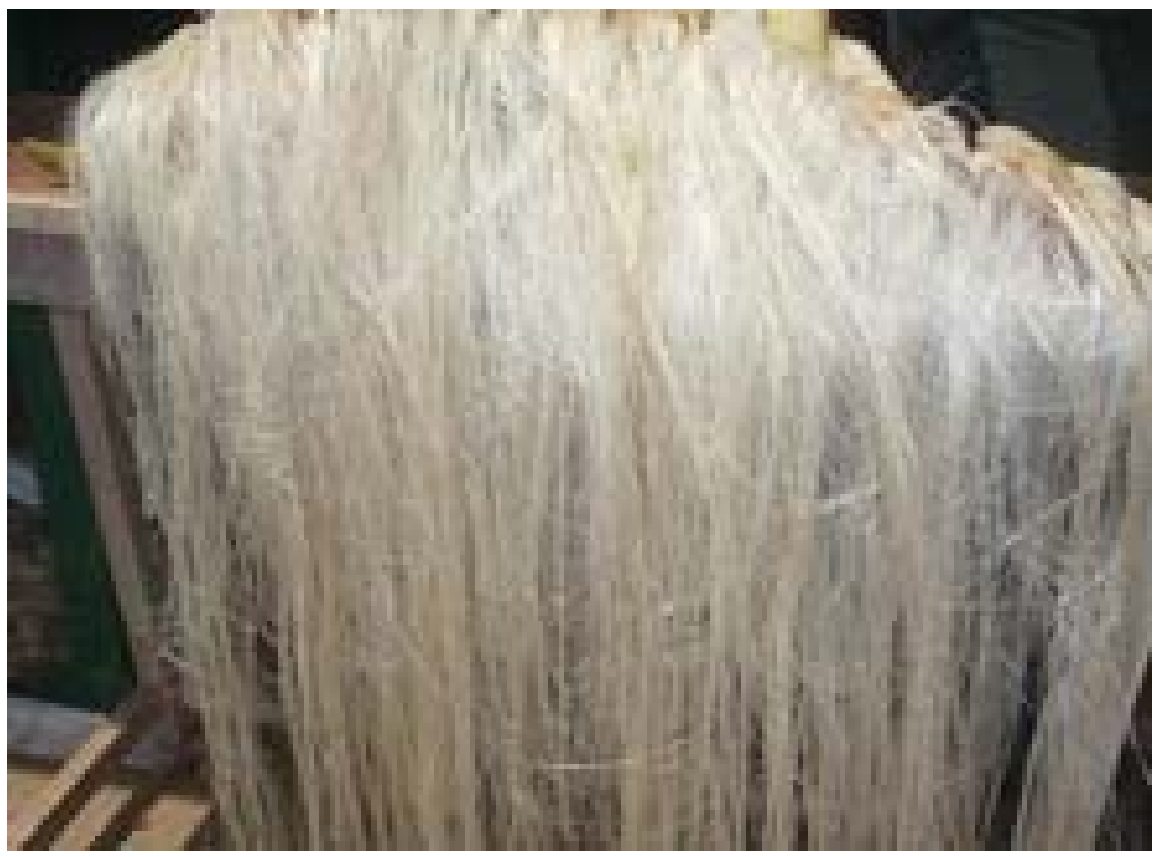

Figure 1. A small packet of PALF fibers. 
The histogram in Fig. 2 reveals a relatively large variation in the diameter, which is a consequence of the non-uniform physical characteristics of a lignocellulosic fiber $[1,3,5-8]$. It should be noticed that the diameter range was $0.10-0.28 \mathrm{~mm}$ with an average of $0.20 \mathrm{~mm}$.

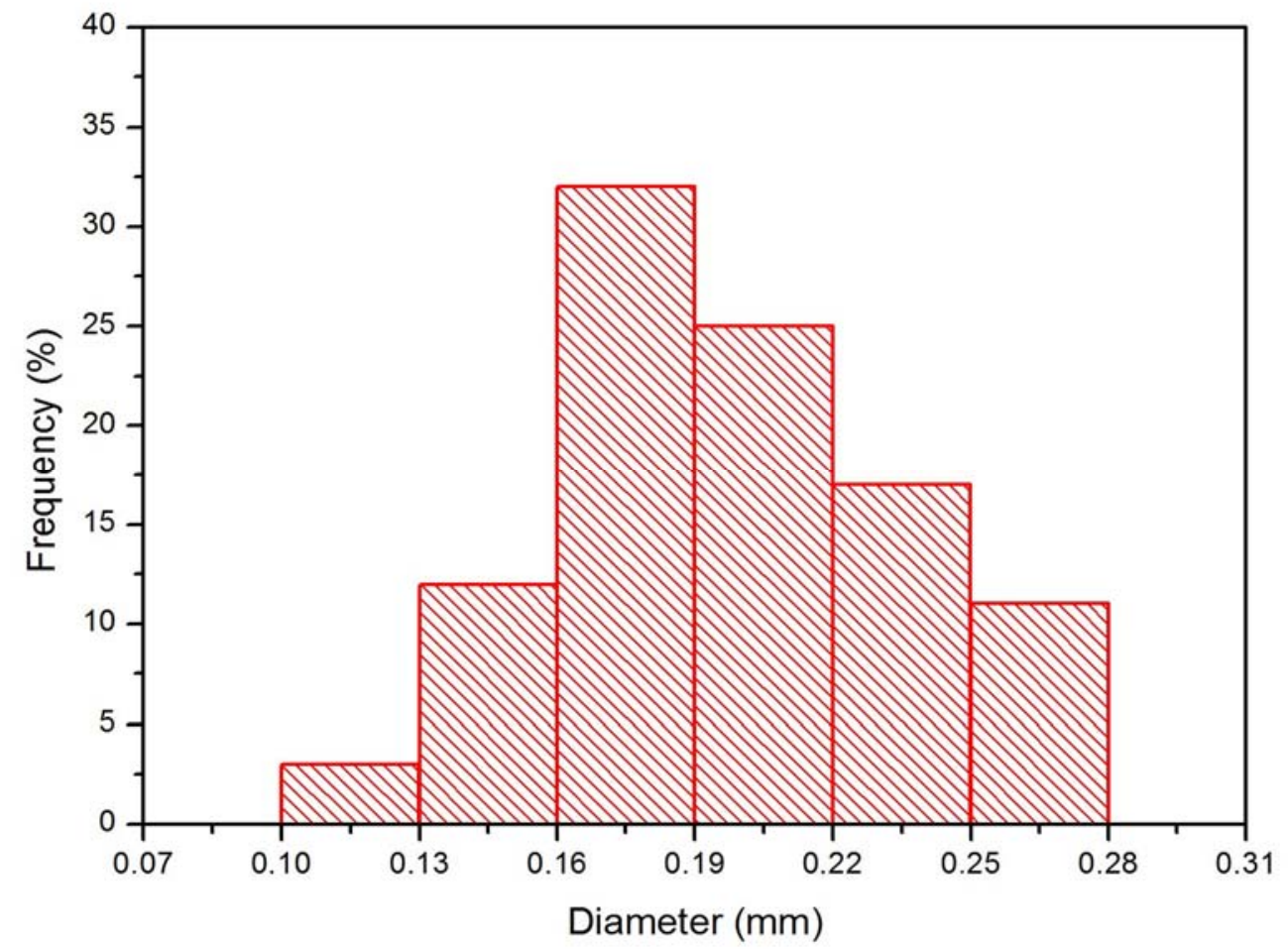

Figure 2. Histogram for the distribution of diameter's PALF fibers.

Composites with up to $30 \%$ in volume of PALF fibers were fabricated by placing the fibers longitudinally aligned inside a steel mold and then pouring the still fluid epoxy resin, was poured onto the fibers and pressured in the mold up to 1 ton. Standard specimens for Izod impact test, with $63 \times 12.7 \times 10 \mathrm{~mm}$, with aligned Fibers along its length. Figure 3 illustrates the Izod impact specimen with standard dimensions. The notch with $2.54 \mathrm{~mm}$ in depth, angle of $45^{\circ}$ and a tip curvature radius of $0.25 \mathrm{~mm}$ was machined with a DIN 847 milling tool. For each volume fraction of fiber, 10 specimens were impact tested in a PANTEC hammer pendulum to ensure a statistical validation.

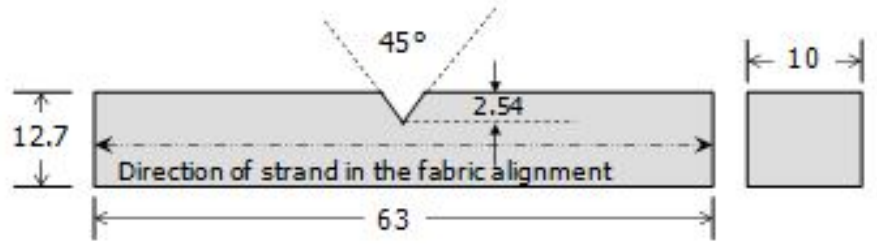

Figure 3. Izod standard specimen schematic.

\section{RESULTS AND DISCUSSION}

The table 1 shows the results obtained in the izod impact tests of epoxy composites reinforced with continuous and aligned PALF fibers with different volume fractions. 
Table 1. Izod impact energy for epoxy composites reinforced with continuous and aligned PALF fibers.

\begin{tabular}{|c|c|}
\hline Volume Fraction of PALF Fibers (\%) & Izod Impact Energy (J/m) \\
\hline 0 & $16.53 \pm 1.80$ \\
\hline 10 & $113.43 \pm 52.43$ \\
\hline 20 & $187.69 \pm 47.89$ \\
\hline 30 & $483.82 \pm 85.32$ \\
\hline
\end{tabular}

The figure 4 shows de macrostructure appearance of the specimens after the izod impact tests for each volume fraction of fibers tested. It should be noted that the specimens with more than $20 \%$ did not break and the fracture is not complete, that shows the izod impact energy was underestimated and should be higher if the specimens were completely separate.

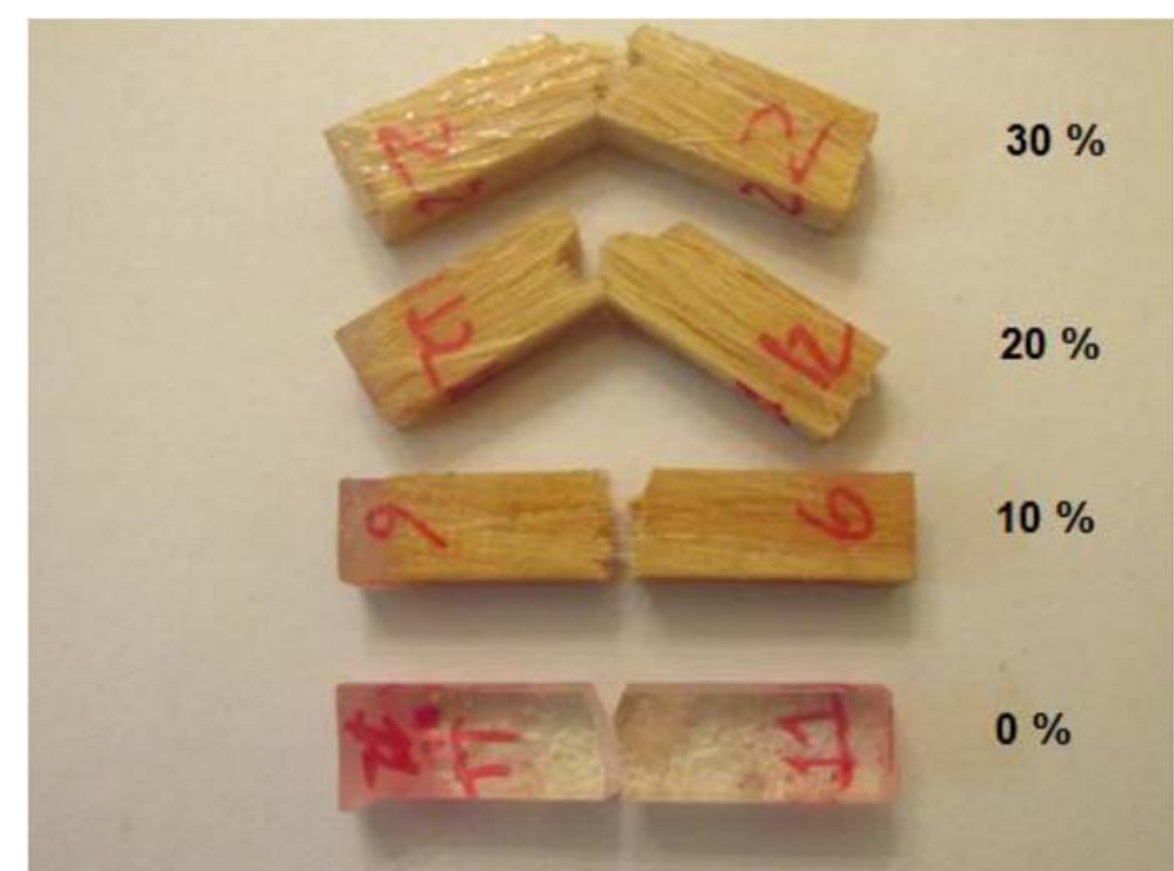

Figure 4. Macrostructure appearance of the specimens for each volume fraction of PALF fiber.

The variation of the izod impact energy with amount of PALF fiber into the epoxy composites is shown in fig. 5 . 


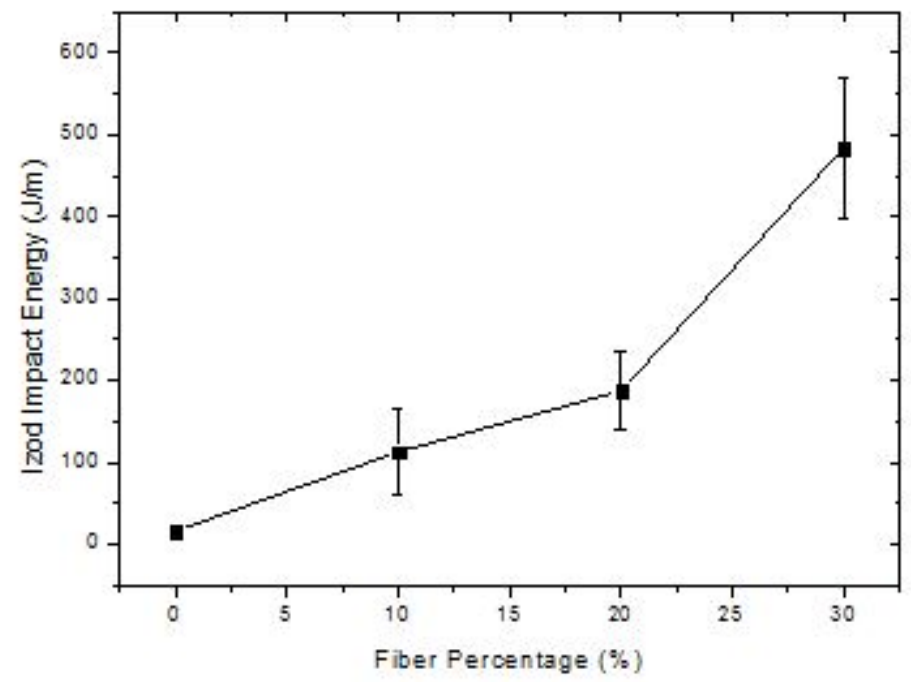

Figure 5. Izod impact energy as a function of PALF fiber.

The figure 5 shows that the incorporation of PALF fibers into the epoxy matrix improves the impact toughness of the composite. The high dispersion of values, given by the standard deviation associated with the higher fiber percentage it is because the heterogeneous characteristic of the lignocellulosic fibers [2].

The relatively low interface strength between the polymeric matrix, that is hydrophobic, and the hydrophilic natural fiber contributes to an ineffective load transfer from the matrix to a longer fiber. Therefore, a higher impact energy is necessary for the rupture of specimen and in a greater fracture surface[9].

In comparison with the pure epoxy specimen, the type of rupture in the composites were not the same. In the pure epoxy specimen the rupture was totally transversal, as expected in a monolithic polymer. In composites reinforced with fibers the rupture is no longer completely transversal. The cracks nucleated at the notch will initially propagate transversal through the epoxy matrix when the crack front reaches a fiber, the rupture will proceed through the interface, as an indication by the fibers' action.

This behavior corroborates the rupture mechanism of cracks that propagate preferentially in between the fiber surface and the epoxy matrix due to the low interfacial strength [9]. The higher absorbed impact energy with the increase of the amount of fiber occurs by the greater fracture area associated with the aligned and continuous PALF fiber acting as reinforcement for the composite.

\section{CONCLUSIONS}

- Composites of aligned PALF fibers reinforcing an epoxy matrix display a significant increase in the toughness, measures by the Izod impact test, as a function of the amount of the fiber.

- Most of this increase in toughness is apparently due to the low fiber/epoxy.

- Matrix interfacial shear stress. This results in a higher absorbed energy as a consequence of a longitudinal propagation of the cracks throughout the interface, which generates larger rupture areas, as compared to a transversal fracture. 


\section{Acknowledgements}

The authors thank the support by Brazilian agencies: CNPq, CAPES, FAPERJ and TECNORTE/FENORTE.

\section{REFERENCES}

1. D. Nabi Sahed and J.P. Jog, "Natural fiber polymer composites: a review", Advances in Polymer Technol., 18 (1999), 221-274.

2. A.K. Mohanty, M. Misra and G. Hinrichsen, "Biofibers, biodegradable polymers and biocomposites: an overview", Macromolecular Mat. And Engineering, 276/277 (2000), 1-24.

3. A .K. Bledzki, and J. Gassan, "Composites Reinforced With Cellulose-Based Fibers". Prog. Polym. Sci, 4 (1999) 221-274.

4. ROHEN, L.A.; MARGEM, F.M.; MONTEIRO, S. N.; NEVES, A.C.C. Tensile strength of epoxy composites reinforced with thinner sisal fibers

5. SIMONASI, N.; MARGEM, F.M.; MONTEIRO, S. N.; LOIOLA, R.L. Tensile test of high strength thinner curaua fiber reinforced polyester matrix composites.

6. S.N. Monteiro, M.V. de Souza, J.R.M. d'Almeida, R.J. Sánchez,. "Sugar cane bagasse waste as reinforcement in low cost composites". Adv. Perform. Mater., 5(3) (1998) 183-191.

7. S.N. Monteiro, F.P.D. Lopes, L.L. Costa, L.C. Motta, L.F.L. Santos Jr., "Study of the buriti waste fiber as a possible reinforcement of polyester composites", Proceedings of REWAS 2008 (Cancun, Mexico, October, 2008) 1-6.

8. $\quad$ S.N. Monteiro, L.F.L. Santos Jr., F.M. Margem, "Mechanical characterization of ramie fiber reinforced polyester composites", Proceedings of the TMS Conference, (New Orleans, LA, USA, March, 2008) 1 -6.

9. $\quad$ S.N. MONTEIRO, R.C.M.P. AQUINO, F.P.D. LOPES, E.A. CARVALHO and J.R.M. D’ALMEIDA, Tenacidade ao entalhe por impacto charpy de compósitos de poliéster reforçados com fibras de piaçava. Rev. Mater., v.11, p.204-210, 2006 